\title{
Rancang Bangun Sistem Pelayanan Jasa Bubut Berbasis Web Pada CV. Sukses Abadi Jaya Tangerang
}

\author{
Ari Febrianto ${ }^{1}$, Popon Handayani ${ }^{2}$ \\ ${ }^{1}$ AMIK BSI Cimone \\ J1. Gatot Subroto Blok B No.8, Cimone, Tangerang \\ e-mail: arryworld@gmail.com \\ ${ }^{2}$ STMIK Nusa Mandiri \\ J1.Kramat Raya No.18 Jakarta Pusat \\ e-mail: popon.pph@nusamandiri.ac.id
}

Cara Sitasi: Febrianto, A., \& Handayani, P. (2019, Maret). Rancang Bangun Sistem Pelayanan Jasa Bubut Berbasis Web Pada CV. Sukses Abadi Jaya Tangerang. (S. Dalis, Ed.) Paradigma - Jurnal Komputer dan Informatika, 21(1), 1-8. doi:10.31294/ p.v21i1.4471

\begin{abstract}
The development of the world's auto industry that is very significant, promoted demand for spare parts and fitting services. In improving the performance of a company can take advantage of science and information technology. To date $C V$. The lasting success of this Triumphant doing marketing and promotion with the conventional way i.e. waiting for buyers or service users come in and out of the mouth to the mouth, it needs a breakthrough promotions and delivery information more effectively and efficiently. In the system of bookkeeping results in sales of products and services still use the system manually, that is only written in the great book. In this case the company workshop lathe takes innovation to change the bookkeeping systems still using manual systems into a computerized system for fast and accurate results. Based on the foregoing, required a data processing information system design and means of promotion in the workshop, then writers interested in creating a system of web-based services lathe using the programming language PHP and MySQL with the waterfall method for CV. Successful Perennial Jaya so that later the party workshop will be able to easily do the promotion and inputting data
\end{abstract}

Keywords: System Designing, Service, Lathe Services, Web

\section{PENDAHULUAN}

Perkembangan dunia industri otomotif yang sangat signifikan, berimbas pada permintaan akan sparepart dan jasa bubut. Tuntutan akan berbagai informasi yang cepat dan akurat sangatlah berpengaruh dalam dunia bisnis. Dalam meningkatkan kinerjanya suatu perusahaan dapat memanfaatkan ilmu pengetahuan dan teknologi informasi sebagai sarana pengolahan data secara cepat, tepat dan akurat.

Bengkel bubut hadir melayani dan berlomba-lomba menjalin kerjasama dengan perusahaan otomotif tersebut untuk memenuhi jasa pembuatan sparepart. Ketatnya persaingan bengkel bubut pada umumnya yang semakin meningkat, perlu adanya penerapan sistem pelayanan jasa secara komputerisasi dan terintegrasi yang memudahkan dalam melakukan promosi, penyimpanan, dan pengolahan data.

CV.Sukses Abadi Jaya merupakan perusahaan yang bergerak dibidang jasa bubut atau pembuatan partpart otomotif. Hingga saat ini CV.Sukses Abadi
Jaya ini melakukan pemasaran dan promosi dengan cara konvensional yaitu menunggu pembeli atau pemakai jasa datang dan dari mulut kemulut, perlu suatu terobosan promosi dan penyampaian informasi yang lebih efektif dan efisien. Dalam sistem pembukuan hasil penjualan produk dan jasa masih menggunakan sistem secara manual, yaitu hanya ditulis dalam buku besar. Dalam hal ini perusahaan bengkel bubut ini membutuhkan inovasi untuk mengubah sistem pembukuan yang masih menggunakan sistem manual kedalam sistem yang terkomputerisasi untuk hasil yang cepat dan akurat. Berdasarkan hal tersebut, diperlukan sebuah desain sistem informasi pengolahan data dan sarana promosi pada bengkel.

\section{METODOLOGI PENELITIAN}

1. Metode Pengembangan Perangkat Lunak Metode yang digunakan pada pengembangan perangkat lunak ini menggunakan model waterfall, menurut (Rosa \& Shalahuddin, 2015)menjelaskan bahwa "model SDLC air 
terjun (waterfall) sering juga disebut model sekuensial linier (sequential linear) atau alur hidup klasik (classic life cycle). Model air terjun menyediakan alur hidup terurut mulai dari analisis, desain, pengodean, pengujian, dan pendukung (support)."

Tahapan-tahapan yang terdapat dalam model waterfall adalah sebagai berikut (Rosa \& Shalahuddin, 2015)

a. Analisis Kebutuhan Perangkat Lunak

Pada proses ini penulis mengambil data pelanggan, data barang, data surat jalan masuk dan keluar, data invoice untuk memenuhi kebutuhan perangkat lunak yang akan dibuat.

b. Desain

Pada proses ini merupakan tahapan dimana dilakukan penuangan perancangan sistem terhadap solusi dari permasalahan yang ada dengan menggunakan perangkat permodelan sistem seperti ERD (Entity Relationship Diagram) dan LRS (Logical Record Structure).

c. Pembuatan Kode Program

Membangun sistem dengan menggunakan bahasa PHP, HTML, SQL menggunakan software Adobe Dreamweaver CS6 dan Adobe Photoshop CS6. Sedangkan membangun database menggunakan MySQL dengan tool open source phpMyAdmin.

d. Pengujian

Metode yang digunakan untuk melakukan pengujian adalah metode Blackbox, sebuah metode yang hanya memperhatikan masukan dan keluaran tanpa memperhatikan proses yang terjadi dengan pendekatan acceptance and operational testing, yang dimana pengujian dilakukan oleh calon pengguna.

e. Pendukung atau pemeliharaan

Tidak menutup kemungkinan sebuah perangkat lunak mengalami perubahan ketika sudah dikirimkan ke user. Perubahan bisa terjadi karena adanya kesalahan yang muncul dan tidak terdeteksi saat pengujian atau perangkat perangkat lunak harus beradaptasi dengan lingkungan baru. Tahap pendukung atau pemeliharan dapat mengulangi proses pengembangan mulai dari analisis spesifikasi untuk perubahan perangkat lunak yang sudah ada, tapi tidak untuk membuat perangkat lunak baru.

\section{Teknik Pengumpulan Data}

Teknik pengumpulan data yang digunakan adalah:

a. Observasi

Melakukan pengamatan dan mempelajari kekurangan kemudian mendefinisikan masalah terhadap sistem yang sedang berjalan pada CV.Sukses Abadi Jaya yang bertempat di Ruko Grand Sutera Blok K1 No.5 Kutabumi, Pasarkemis Kab.Tangerang.

b. Wawancara

Penulis melakukan wawancara dengan Bapak Sri Yanto selaku owner CV.Sukses Abadi Jaya, untuk mengetahui sistem yang berjalan agar memperoleh data yang tepat dan akurat sesuai sistem yang sedang berjalan.

3. Studi Pustaka

Mempelajari buku-buku literatur, mempelajari jurnal-jurnal terdahulu dan artikel dari internet yang berkaitan dengan penelitian ini.

\subsection{Konsep Dasar Web}

"Rancang adalah proses menganalisa kebutuhan dan mendeskripsikan dengan detail komponen-komponen yang akan diimplementasikan, juga dijelaskan pengertian dari bangun yaitu menciptakan sistem baru atau memperbaiki sistem yang sudah ada" (Winardi, ida Farida, \& Dicky Hariyanto, 2017)

"Sistem merupakan sekelompok elemenelemen yang saling berhubungan, dan bertanggung jawab melakukan proses input sehingga menghasilkan output. Definisi sistem mempunyai peranan yang sangat penting dalam melakukan pendekatan terhadap sistem yang akan dianalisis. Pendekatan sistem yang merupakan kumpulan dari komponen atau elemen-elemen atau subsistemsubsistem merupakan definisi yang lebih luas dibandingkan pendekatan sistem yang lebih menekankan pada prosedurnya" (Misriati, 2015).

"Pelayanan adalah pemberian jasa baik oleh pemerintah, pihak swasta atas nama pemerintah ataupun pihak swasta kepada masyarakat dengan atau tanpa pembayaran guna memenuhi kebutuhan dan kepentingan masyarakat" (Sundari, 2016).

\subsubsection{Website}

"Website atau situs dapat diartikan sebagai kumpulan halaman-halaman yang digunakan untuk menampilkan informasi teks, gambar diam atau gerak, animasi, suara, dan atau gabungan dari semuanya, baik yang bersifat statis maupun dinamis yang membentuk satu rangkaian bangunan yang saling terkait, yang masing-masing dihubungkan dengan jaringan-jaringan halaman" (Sundari, 2016 : 44)

"Internet adalah rangkaian hubungan jaringan komputer yang dapat diakses secara umum diseluruh dunia, yang mengirimkan data dalam bentuk paket data berdasarkan standar internet" (Suryanto , 2018) "Xampp adalah salah satu paket software web server yang terdiri dari Apache, Mysql, Php dan PhpMyAdmin. Proses instalasi xampp sangat mudah, karena tidak perlu memerlukan konfigurasi Apache, Php, dan Mysql secara manual, xampp melakukan instalasi dan konfigurasi secara otomatis" (Fatmawati, 2016: 34).

\subsubsection{Bahasa Pemrograman}


"PHP (Hypertext Preprocessor) merupakan Bahasa pemrograman yang ditujukan untuk membuat aplikasi web. Ditinjau dari pemrosesannya, PHP tergolong berbasis server side. Artinya, pemrosesan dilakukan di server. Hal ini berkebalikan dengan bahasa seperti JavaScript, yang pemrosesannya dilakukan di sisi klien (client side)" (Kadir, 2013: 120).

Menurut (Hidayatullah dan Kawistara, 2017:15) Hypertext Markup Language (HTML) adalah bahasa standard yang digunakan untuk menampilkan halaman web. Yang bisa dilakukan dengan HTML yaitu:

a. Mengatur tampilan dari halaman web dan isinya.

b. Membuat tabel dalam halaman web.

c. Mempublikasi halaman web secara online.

d. Membuat form yang bisa digunakan untuk menangani registrasi dan transaksi via web.

e. Menambahkan objek-objek seperti citra, audio, video, animasi, java applet dalam halaman web.

f. Menampilkan area gambar (canvas) di browser.

"SQL (Structured Query Language) adalah bahasa yang digunakan untuk mengelola data pada RDBMS. SQL awalnya dikembangkan berdasarkan teori aljabar relasional dan kalkulus" (Rosa dan Shalahuddin, 2015: 46).

"CSS (Cascading Style Sheet) adalah sebuah cara untuk memisahkan isi dengan layout dalam halaman-halaman web yang dibuat. Cascading Style Sheet dikembangkan untuk menata gaya pengaturan halaman web. Pada awalnya CSS dikembangkan pada SGML pada tahun 1970 dan terus dikembangkan hingga saat ini CSS telah mendukung banyak bahasa, Cascading Style Sheet memiliki arti gaya menata halaman bertingkat. Yang berarti setiap satu elemen yang telah format, maka anak dari elemen tersebut secara otomatis mengikuti format elemen induknya" (Fatmawati, 2016:34)

\subsubsection{Basis Data}

"Basis data adalah suatu pengorganisasian data dengan tujuan memudahkan penyimpanan dan pengaksesan data"(Kadir, 2013:15)

\subsubsection{Model Pengembangan Perangkat Lunak}

Model yang digunakan pada pengembangan perangkat lunak ini menggunakan model waterfall, menurut Rosa dan Shalahuddin (2015:28) menjelaskan bahwa "model SDLC air terjun (waterfall) sering juga disebut model sekuensial linier (sequential linear) atau alur hidup klasik (classic life cycle). Model air terjun menyediakan alur hidup terurut mulai dari analisis, desain, pengodean, pengujian, dan pendukung (support)". Berikut adalah gambar model air terjun:

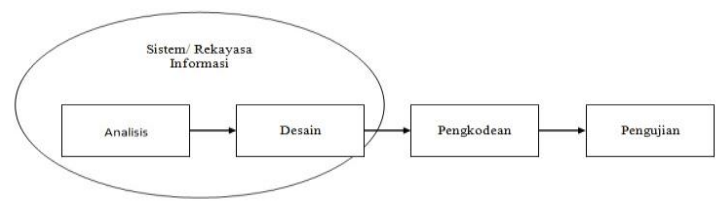

Sumber : Rosa dan Shalahuddin (2015:29)

Gambar 1. Ilustrasi model waterfall

\subsection{Teori Pendukung}

2.2.1 Struktur Navigasi

Menurut (Sunarti, 2015:2) "struktur navigasi adalah susunan menu atau hirarki dari suatu situs yang menggambarkan isi dari setiap halaman dan link atau navigasi tiap halaman pada suatu situs web. Struktur navigasi termasuk struktur terpenting dalam pembuatan suatu multimedia. Strukur navigasi juga memberikan kemudahan dalam menganalisa keinteraktifan seluruh objek dan multimedia bagaimana pengaruh keinteraktifan terhadap pengguna".

\subsubsection{Entity Relationship Diagram (ERD) \\ Menurut Rosa dan Shalahuddin} (2015:53), “ERD adalah bentuk paling awal dalam melakukan perancangan basis data relasional. Jika menggunakan OODBMS maka perancangan ERD tidak perlu dilakukan”. ERD sendiri memiliki beberapa aliran notasi seperti notasi chen (dikembangkan oleh peter chen), Barker (dikembangkan oleh ricarad barker, Ian Palmer, Harry Ellis), notasi Crow's Foot, dan beberapa notasi lain namun yang banyak di gunakan adalah notasi dari chen".

\subsubsection{Logical Record Structure (LRS).}

Menurut Puspitasari, (2016:229) "Sebuah model sistem yang digambarkan dengan sebuah diagram-ER akan mengikuti pola/aturan pemoddengan konversi ke LRS, maka perubahan yang terjadi adalah mengikuti aturan-aturan". Setiap entitas akan diubah kebentuk kotak, sebuah atribut relasi disatukan dalam sebuah kotak bersama entitas jika hubungan yang terjadi pada diagram-ER/ERD :

1. 1:M (One to Many) merupakan relasi bersatu dengan cardinality $\mathrm{M}$.

2. 1:1 (One to One) merupakan relasi bersatu dengan cardinality yang paling membutuhkan referensi,sebuah relasi dipisah dalam sebuah kotak tersendiri (menjadi entitas baru).

3. M:M (many to many) memiliki foreign key sebagai primary key yang diambil dari kedua entitas.

\subsubsection{Implementasi dan Pengujian Web} Menurut Rosa dan Shalahuddin (2015:275), pengujian untuk validasi memiliki beberapa pendekatan sebagai berikut:

1. Black-Box Testing (pengujian kotak hitam) 
Yaitu menguji perangkat lunak dari segi spesifikasi fungsional tanpa menguji desain dan kode program. Pengujian dimaksudkan untuk mengetahui apakah fungsi-fungsi, masukan, dan keluaran dari perangkat lunak sesuai dengan spesifikasi yang dibutuhkan. Pengujian kotak hitam dilakukan dengan membuat kasus uji yang bersifat mencoba semua fungsi dengan memakai perangkat lunak apakah sesuai dengan spesifikasi yang dibutuhkan. Kasus uji yang dibuat untuk melakukan pengujian kotak hitam harus dibuat dengan kasus benar dan kasus salah, misalkan untuk kasus proses login maka kasus uji yang dibuat adalah:

a. Jika user memasukan nama pemakai (username) dan kata sandi (password) yang benar.

b. Jika user memasukan nama pemakai (username) dan kata sandi (password) yang salah, misalnya nama pemakai benar tapi kata sandi salah, atau sebaliknya, atau keduanya salah.

\section{HASIL DAN PEMBAHASAN}

\subsection{Analisa Kebutuhan}

Pada sistem ini pelanggan atau pengunjung dapat melihat informasi-

informasi produk pelayanan jasa yang ada sedangkan admin dapat mengolah data

pemesanan jasa bubut dan mengelola informasiinformasi yang ada di website.

1. Halaman untuk pengunjung

a. Beranda

Pengunjung dapat melihat produk jasa bubut yang ada pada website ini serta dapat melakukan pendaftaran baru di sidebar sebelah kiri.

b. Profil

Pengunjung dapat melihat profil CV. Sukses Abadi Jaya.

c. Pemesanan

Pengunjung dapat melihat produk yang dapat dilayani oleh pihak CV.Sukses Abadi Jaya.

d. Panduan

Pada halaman ini terdapat panduan cara pemesanan jasa bubut.

e. Konfirmasi

Dihalaman ini pengunjung dapat melakukan konfirmasi pembayaran.

f. Bagian Footer

Dibagian footer terdapat kontak, alamat dan buku tamu CV. Sukses Abadi Jaya.

2. Halaman untuk pelanggan yang sudah mendaftar

a. Login

Pelanggan yang sudah mendaftar dapat login sesuai username dan password yang didaftarkan. b. Beranda

Pelanggan dapat melihat produk jasa bubut yang ditawarkan serta dapat melakukan pemesanan.

c. Profil

Pelanggan dapat melihat profil dari CV. Sukses Abadi Jaya.

d. Pemesanan

Pelanggan dapat melihat dan memesan jasa yang ditawarkan pada website ini.

e. Panduan

Pada halaman ini terdapat panduan cara pemesanan dan cara pembayaran.

f. Konfirmasi

Dihalaman ini pelanggan dapat melakukan konfirmasi pembayaran.

g. Transaksi

Berada di sidebar kiri dimana terdapat navigasi keranjang belanja yang menampilkan pesanan jasa bubut yang sudah dipilih, navigasi tampil transaksi untuk melihat daftar pemesanan yang pernah pelanggan pesan.

h. Logout

Pelanggan dapat logout keluar dari transaksi pemesanan.

i. Bagian Footer

Dibagian footer terdapat kontak, alamat dan buku tamu CV. Sukses Abadi Jaya

3. Halaman untuk admin

a. Login

Admin dapat login terlebih dahulu sebelum masuk ke halaman admin

b. Index

Admin dapat melakukan login dan logout

c. Dashboard

Dihalaman ini terdapat kata sambutan "Selamat datang...! Anda login sebagai Administrator".

d. Data Provinsi

Admin dapat mengelola serta menambahkan data provinsi dan biaya kirimnya.

e. Data Kategori

Admin dapat mengelola serta menambahkan data kategori.

f. Data Barang

Admin dapat mengelola serta menambahkan data barang.

g. Data Pelanggan

Admin dapat melihat serta mengelola data pelanggan yang sudah mendaftar.

h. Pemesanan barang

Admin dapat melihat serta mengelola daftar pesanan barang dan dapat melihat design yang diupload oleh pelanggan .

i. Konfirmasi Transfer

Admin dapat melihat dan mengelola data konfirmasi dari pelanggan yang sudah melakukan transfer pembayaran dan dapat 
melihat bukti transfer yang diupload oleh pelanggan.

j. Laporan

Admin dapat melihat serta mengelola setiap data yang ada pada laporan seperti laporan pemesanan masuk-periode, laporan pemesanan lunas-tanggal, laporan pemesanan lunas-periode.

k. Data Admin

Admin dapat melihat serta mengelola dan juga dapat menambahkan dataadmin lagi.

1. Data Web

Admin dapat mengelola data perusahaan yang dijadikan suatu informasi untuk bagian front-end.

m. Ganti Password

Admin dapat mengganti password lama dengan password yang baru.

n. Logout

Admin dapat keluar dari halaman admin.

\subsection{Entity Relationship Diagram}

1. ERD

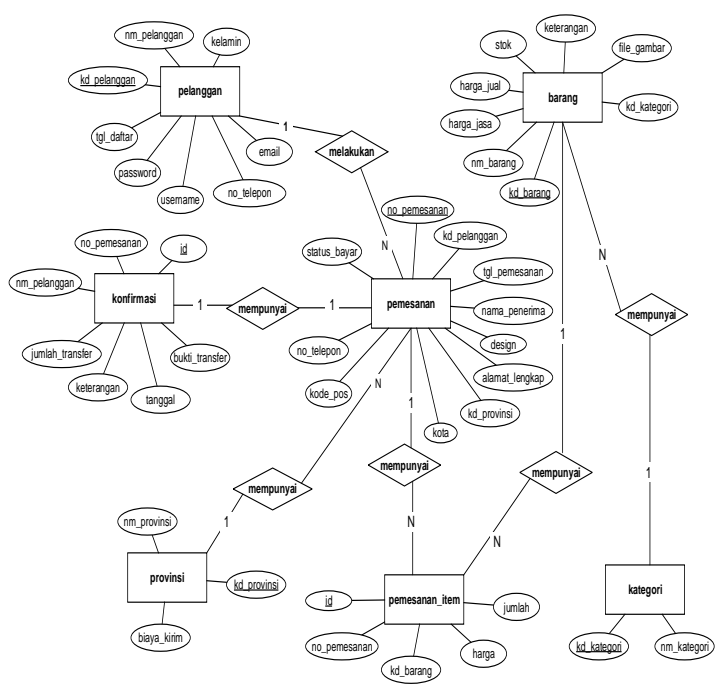

Sumber: Hasil Penelitian(2018)

Gambar 7. Entity Relationship Diagram (ERD)

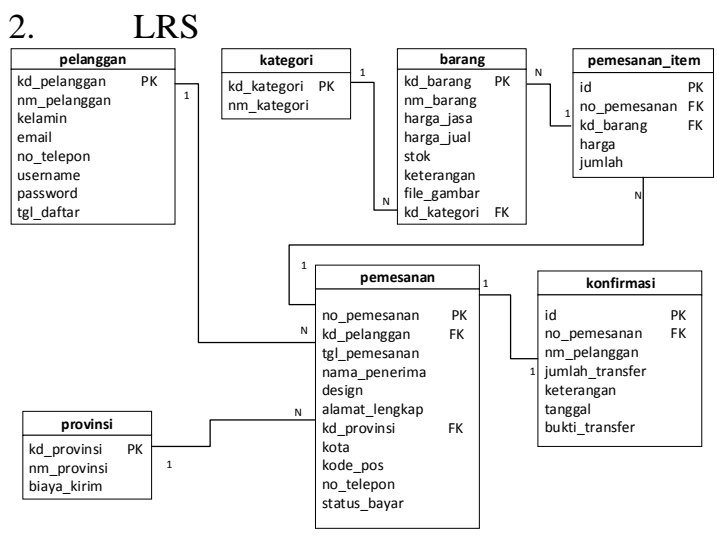

Sumber: Hasil Penelitian(2018)

Gambar 8. Logical Record Structure (LRS)
3.5 Spesifikasi Program

1. Struktur Navigasi Halaman Index Pelanggan

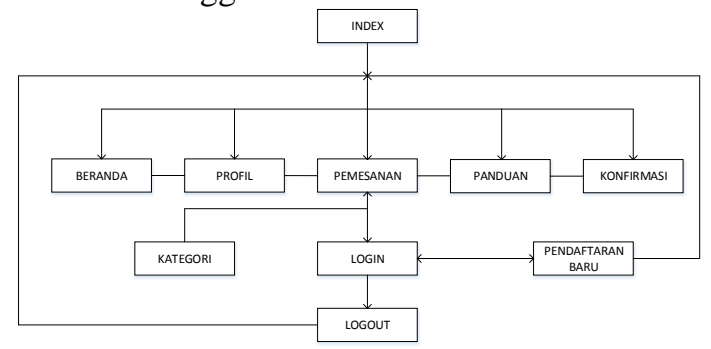

Sumber: Hasil Penelitian(2018)

Gambar 9. Struktur Navigasi Halaman Index Pelanggan

2. Struktur Navigasi Halaman Index Admin

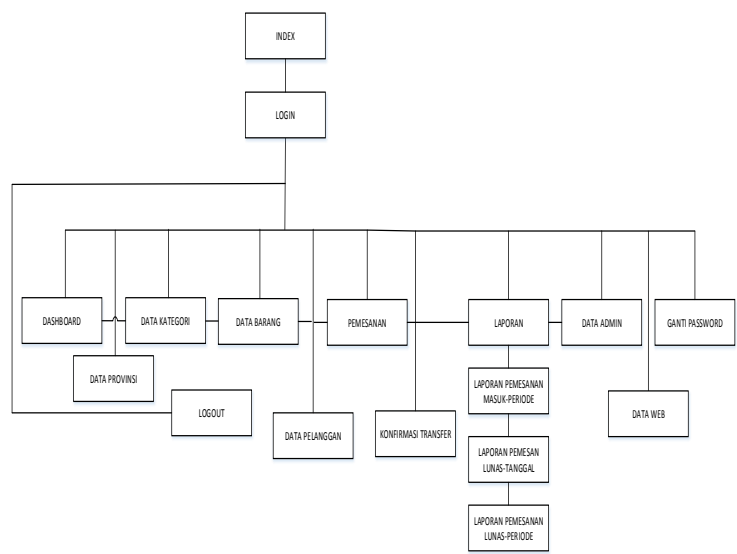

Sumber: Hasil Penelitian(2018)

Gambar 10. Struktur Navigasi Halaman Index Admin

\subsection{Implementasi}

Implementasi rancangan antar muka pada aplikasi pelayanan jasa bubut berdasarkan hasil rancangan antar muka.
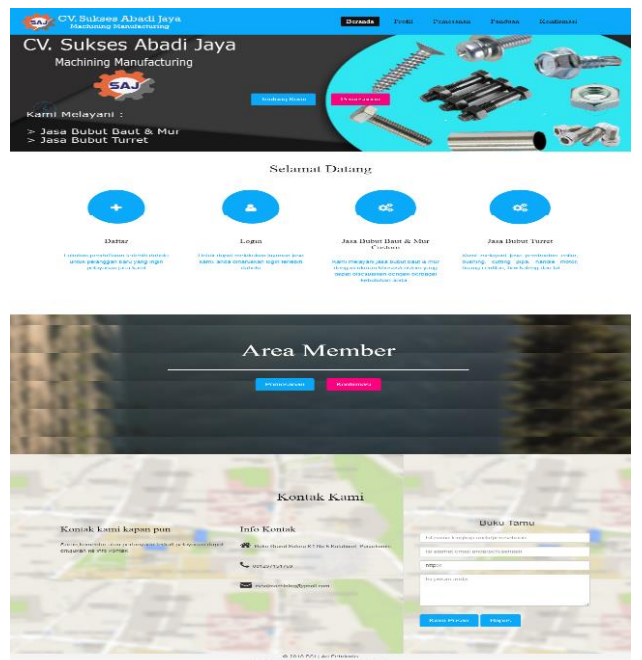

Sumber: Hasil Penelitian(2018)

Gambar 11. Halaman Beranda 


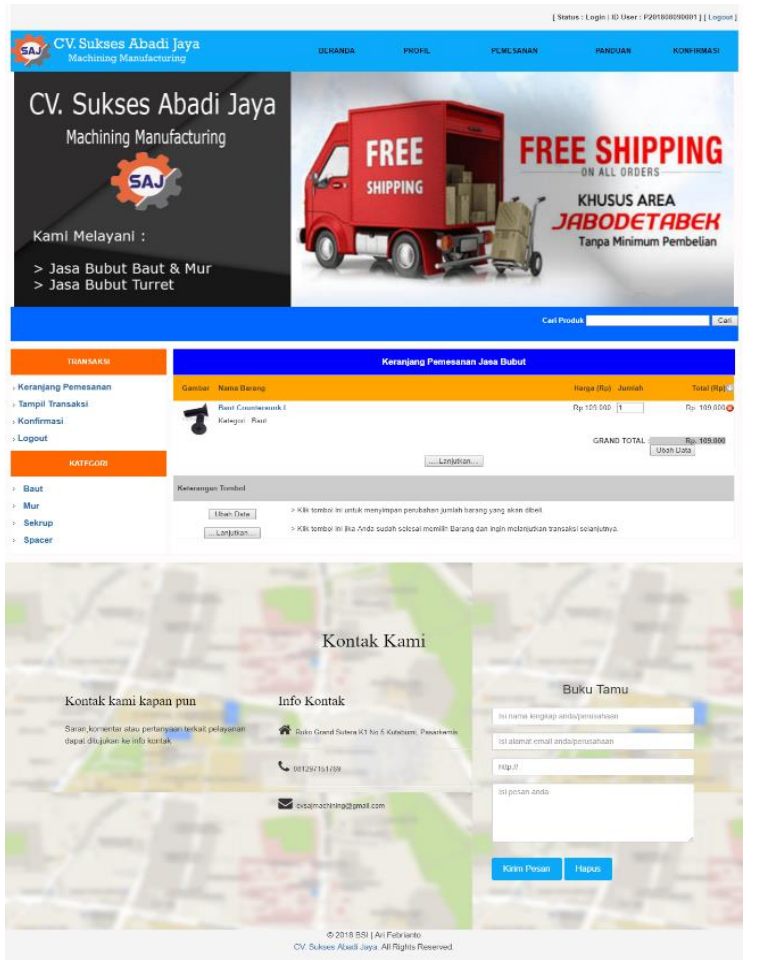

Sumber: Hasil Penelitian(2018)

Gambar 13. Halaman Keranjang Pesanan
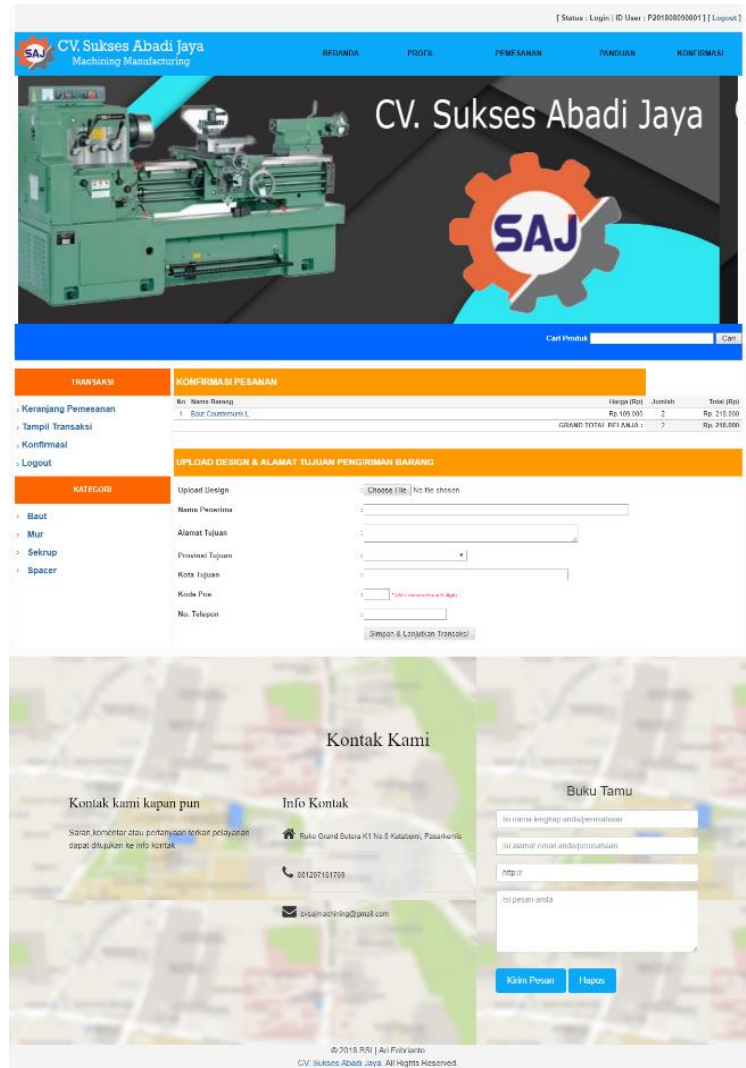

Sumber: Hasil Penelitian(2018)

Gambar 14. Halaman Transaksi

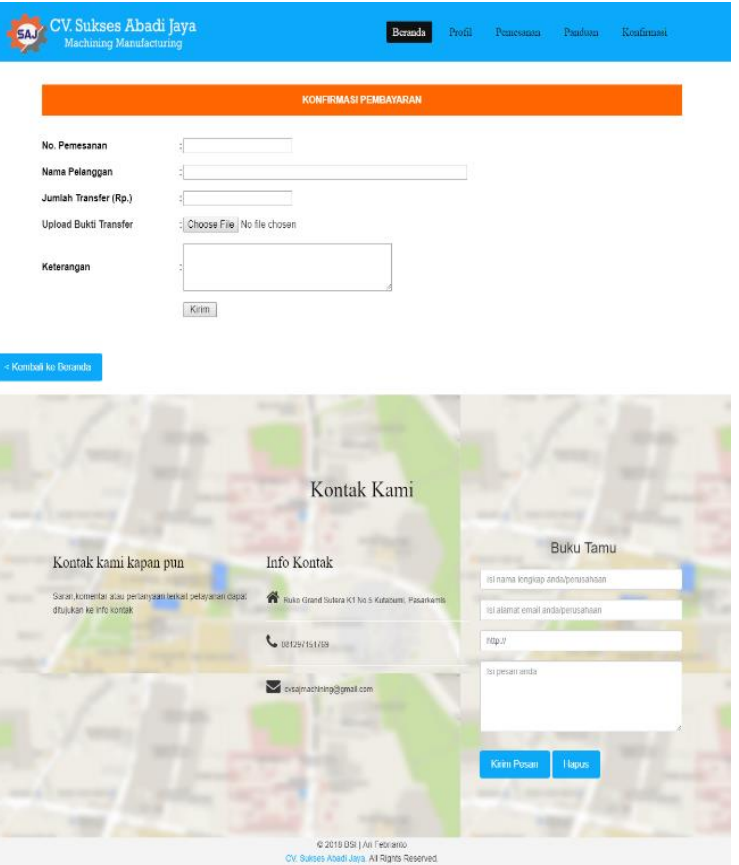

Sumber: Hasil Penelitian(2018)

Gambar 15. Halaman Konfirmasi

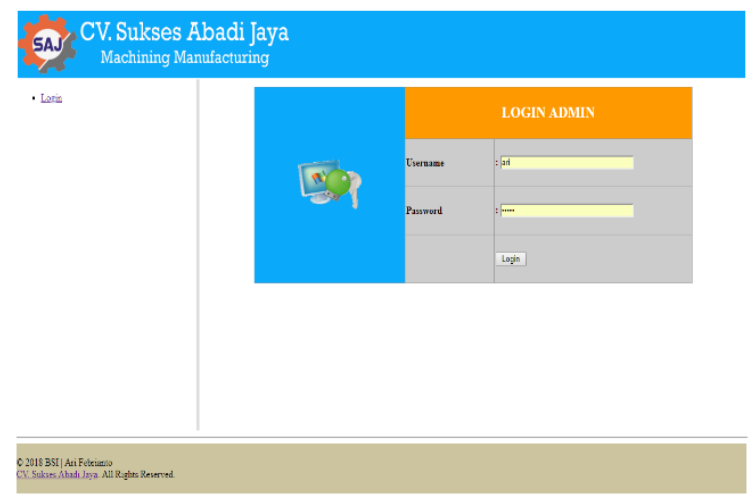

Sumber: Hasil Penelitian(2018) Gambar 16. Halaman Login Admin

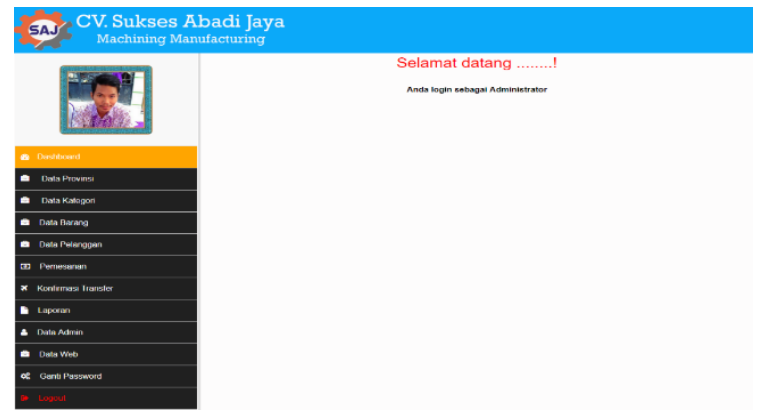

Sumber: Hasil Penelitian(2018)

Gambar 17. Halaman Dashboard Admin 


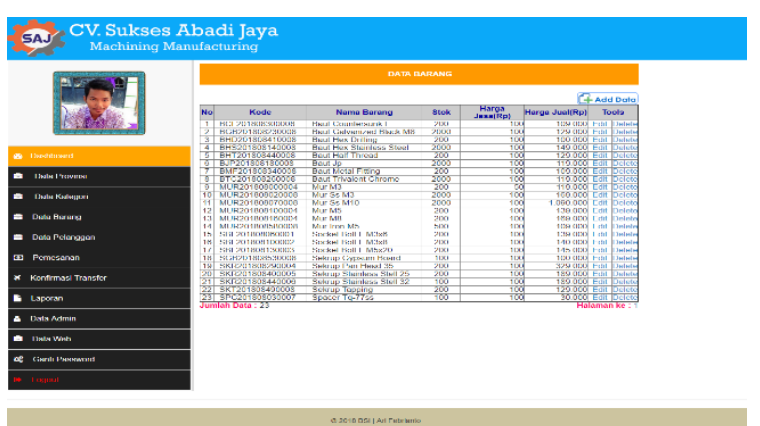

Sumber: Hasil Penelitian(2018)

Gambar 18. Halaman Data Barang

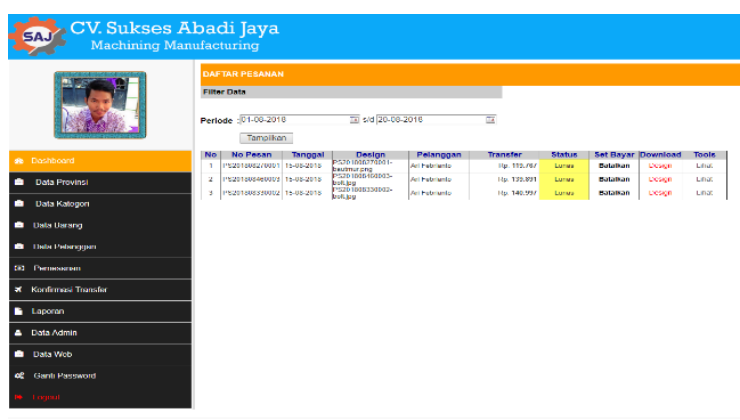

Sumber: Hasil Penelitian(2018)

Gambar 19. Halaman Pemesanan

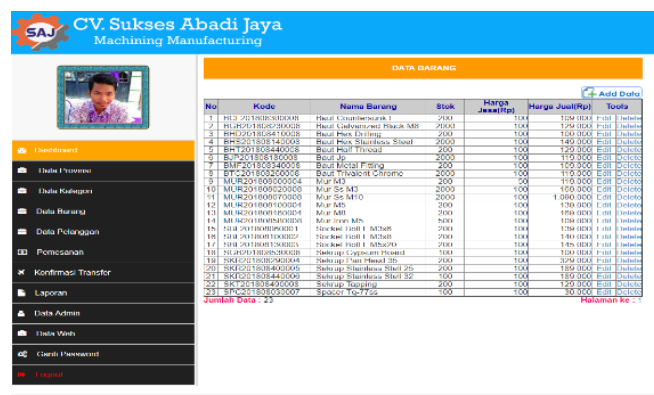

Sumber: Hasil Penelitian(2018)

Gambar 20. Halaman Data Konfirmasi Transfer

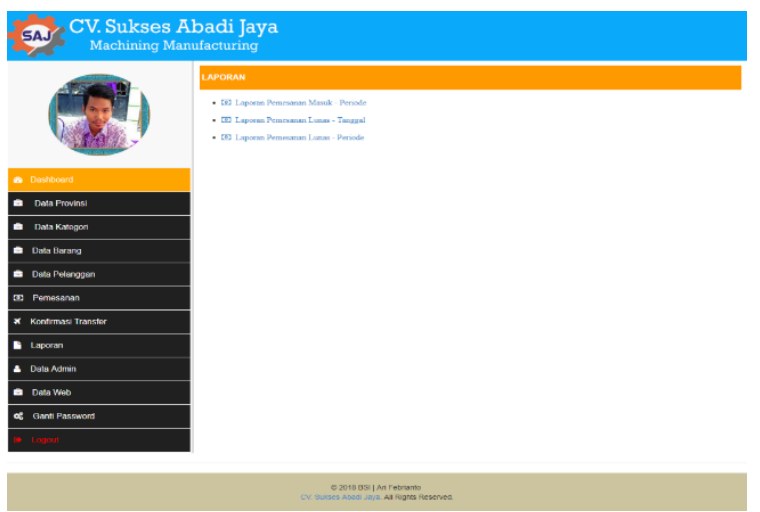

Sumber: Hasil Penelitian(2018)

Gambar 21. Halaman Laporan

\subsection{Pengujian Unit}

Tabel III.12.

Hasil Pengujian Black Box Testing Halaman Login

\begin{tabular}{|c|c|c|c|c|c|}
\hline No & $\begin{array}{l}\text { Skenario } \\
\text { Pengujian }\end{array}$ & Test Case & $\begin{array}{l}\text { Hasil Yang } \\
\text { Diharapkan }\end{array}$ & $\begin{array}{c}\text { Hasil } \\
\text { Pengujian }\end{array}$ & Kesimpulan \\
\hline 1 & $\begin{array}{l}\text { Username } \\
\text { dan } \\
\text { Password } \\
\text { tidak diisi } \\
\text { kemudian } \\
\text { klik tombol } \\
\text { login }\end{array}$ & $\begin{array}{l}\text { Username : } \\
\text { (kosong) } \\
\text { Password : } \\
\text { (kosong) }\end{array}$ & 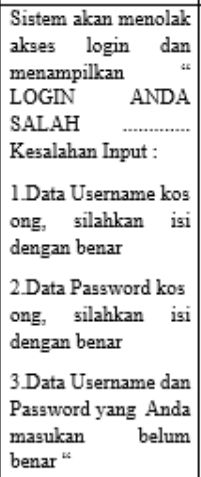 & $\begin{array}{l}\text { Sesuai } \\
\text { Harapan }\end{array}$ & Valid \\
\hline 2 & $\begin{array}{l}\text { Mengetikan } \\
\text { Username } \\
\text { dan } \\
\text { Password } \\
\text { tidak diisi } \\
\text { kemudian } \\
\text { klik tombol } \\
\text { login }\end{array}$ & $\begin{array}{l}\text { Username: } \\
\text { (ari) } \\
\text { Password : } \\
\text { (kosong) }\end{array}$ & $\begin{array}{l}\text { Sistem akan menolak } \\
\text { akses login dan } \\
\text { menampilkan } \\
\text { LOGIN ANDA } \\
\text { SALAH …….. } \\
\text { Kesalahan Input : } \\
\text { 1.Data Password kos } \\
\text { ong, silahkan isi } \\
\text { dengan benar } \\
\text { 2.Data Username dan } \\
\text { Password yang Anda }\end{array}$ & $\begin{array}{l}\text { Sesuai } \\
\text { Harapan }\end{array}$ & Valid \\
\hline & & & \begin{tabular}{|l}
$\begin{array}{l}\text { masukan } \\
\text { benar }{ }^{\circ}\end{array}$ \\
belum
\end{tabular} & & \\
\hline 3 & $\begin{array}{l}\text { Ugemame } \\
\text { tidak diisi } \\
\text { dan } \\
\text { Password } \\
\text { diisi } \\
\text { kemudian } \\
\text { klik tombol } \\
\text { login }\end{array}$ & $\begin{array}{l}\text { Username : } \\
\text { (kosong) } \\
\text { Password: } \\
\text { (user) }\end{array}$ & 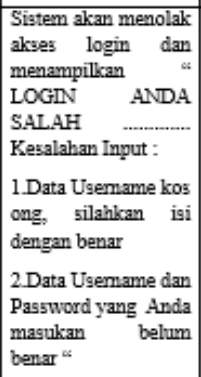 & $\begin{array}{l}\text { Sesuai } \\
\text { Harapan }\end{array}$ & Valid \\
\hline 4 & $\begin{array}{l}\text { Mengetikan } \\
\text { Salah Satu } \\
\text { kondiai } \\
\text { galah pada } \\
\text { ugername } \\
\text { atau } \\
\text { password } \\
\text { kemudian } \\
\text { klik tombol } \\
\text { login }\end{array}$ & $\begin{array}{l}\text { Ugername : } \\
\text { ari } \\
\text { (benar) } \\
\text { Password : } \\
\text { (salah) }\end{array}$ & $\begin{array}{l}\text { Siatem akan menolak } \\
\text { akses login dan } \\
\text { menampilkan } \\
\text { LOGNN ANDA } \\
\text { SALLAH } \\
\text { Kesalahan Input : } \\
\text { 1.Data Usemame dan } \\
\text { Password yang Anda } \\
\text { masukan belum } \\
\text { benar " }\end{array}$ & $\begin{array}{l}\text { Sesuai } \\
\text { Harapan }\end{array}$ & Valid \\
\hline 5 & $\begin{array}{l}\text { Mengetikan } \\
\text { usemame } \\
\text { dan } \\
\text { password } \\
\text { dengan data } \\
\text { yang benar } \\
\text { kemudian } \\
\text { klik tombol } \\
\text { login }\end{array}$ & $\begin{array}{l}\text { Username: } \\
\text { ari } \\
\text { (benar) } \\
\text { Password: } \\
\text { admin } \\
\text { (benar) }\end{array}$ & $\begin{array}{l}\text { Siatem menerima } \\
\text { akses login dan } \\
\text { kemudian langsung } \\
\text { menampilkan memu } \\
\text { utama }\end{array}$ & $\begin{array}{l}\text { Sesuai } \\
\text { Harapan }\end{array}$ & Valid \\
\hline
\end{tabular}

\section{KESIMPULAN}

1. Sistem ini mempermudah pengguna dalam mengelola data pelanggan, barang, pemesanan 
serta mempermudah dalam membuat laporan yang dibutuhkan.

2. Struktur navigasi yang digunakan dalam sistem pelayanan jasa bubut ini adalah struktur navigasi komposit sehingga dapat memberikan keinteraksian yang lebih tinggi.

3. Dengan adanya website ini akan memberikan efisiensi waktu dan lebih praktis sehingga pelanggan tidak perlu datang ke bengkel untuk melakukan pemesanan jasa bubut.

4. Jangkauan promosi lebih luas karena siapapun dapat mengakses website ini sehingga memberikan kemudahan bagi pelanggan dalam mendapatkan informasi secara cepat.

\section{REFERENSI}

Rosa \& Shalahuddin, (2015). Rekayasa Perangkat Lunak Terstruktur Dan Berorientasi Objek.Bandung: Informatika)

Fatmawati. (2016). Perancangan Sistem Informasi Pemesanan Katering Berbasis Web Pada Rumah Makan Tosuka Tangerang. Jurnal Teknik Komputer AMIK BSI, II(2), 33-41. Retrieved

from https://ejournal.bsi.ac.id/ejurnal/index.php/jtk/ article/view/1609

Kadir, A. (Yogyakarta: M. (2013). Pemrograman Database MySQL Untuk Pemula.

Misriati, T. (2015). Rancang Bangun Sistem Pelayanan Jasa Pengecatan Suku Cadang Kendaraan Bermotor. Jurnal Teknik Komputer, 1(1), 123-133. Retrieved from http://ejournal.bsi.ac.id/ejurnal/index.php/jtk/a rticle/view/243

Rosa, \& Shalahuddin, M. (2015). Rekayasa Perangkat Lunak Terstruktur Dan Berorientasi Objek.
Sundari, J. (2016). Sistem Informasi Pelayanan Puskesmas Berbasis Web. IJSE - Indonesian Journal on Software Engineering, 2(1), 44-49. Retrieved from http://ejournal.bsi.ac.id/jurnal/index.php/ijse/ar ticle/view/665/556

Suryanto, A., \& Informatika, B. S. (2018). Rancang Bangun Sistem Informasi Pendaftaran Artis Berbasis, (April). https://doi.org/10.13140/RG.2.2.16105.80483 Winardi, A., ida Farida, \& Dicky Hariyanto. (2017). Rancang Bangun Sistem Informasi Manajemen Bengkel. IJSE - Indonesian Journal on Software Engineering, 3(2), 8-14. Retrieved

from http://ejournal.bsi.ac.id/ejurnal/index.php/ijse/ article/view/2813/1837

\section{PROFIL PENULIS}

ARI FEBRIANTO lahir di Jakarta 2 Februari

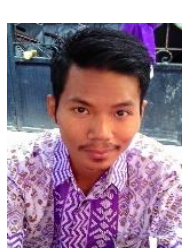
1992, Tahun 2018 Lulus dari Program Diploma Tiga AMIK Bina Sarana Informatika Cimone, Tangerang.

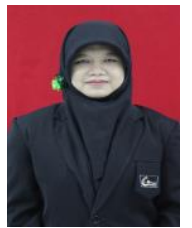

POPON HANDAYANI lahir di Jakarta 24 Juni 1988, berprofesi sebagai seorang dosen pada STMIK Nusa Mandiri dari tahun 2016. 